\title{
HLA-DQA1 Gene
}

National Cancer Institute

\section{Source}

National Cancer Institute. HLA-DQA1 Gene. NCI Thesaurus. Code C71265.

This gene plays a role in antigen presentation and immunoregulation. 